「繊維と繊維学会の将来」特集

\title{
繊維学会入門
}

\section{川口春 馬}

\section{はじめに}

コンピューターをはじめ便利な道具が周りに満ち満ち ていながら，操作法を学ぶのが面倒とか，新しいことを やりはしめる時間がないとかの理由で，十分にそれらを 活かしきれていないことが多い. 学会にしても同じこと. もっと良く知るともっと自分のためになるのに，ついつ い通り一遍のつき合いで過ごしてしまっている．纎維学 会に対してそんな距離感をもっておられる方々に、これ から、繊維学会のあれこれをお示しし，繊維学会といい 関係になっていただくお手伝いをしてみたい.

\section{繊維学会は必要か}

個人でも，グループでも，さらに大きな組織でも，そ の存在意義, その存在価値を確かめないと, 安心して存 立できないし，前向きに活動していけない。「あなたは大 事なひとですよ」と囁かれれば誰でも“よ一し頑張るか” という気持ちになるように，纎維学会にもその存在の必 要性を明示して意気を高めることから始めたい．

私がはじめて高分子を習ったとき，高分子は，繊維と プラスチックスとゴムとの 3 つに分類されると聞いた。

その分類が今もそのまま通用するとは思われないが， 30 年前はそれでよかった３つのうちで繊維が特に長い歴 史を持つとも教えられた，歴史といえば，数多くの学会 の中で繊維学会は長い歴史を誇る学会のひとつである.

䑰維学会は設立されて今年で54年を数え, 気の早い人は そろそろ還暦の準備を始めようとしている，関連する学 会である高分子学会より10年ほど年長である，学問の分 野で見ると，先の分類で述へたように，高分子学会の方
が綫維学会よりテリトリーが広い、会員数も約 $13000 ： 2300$ と 5 倍の違いがある。高分子学会は，その中に26の研究 会を抱えており，その中に䋐維材料研究会というものも ある。もちろん, 繊維材料研究会のアクティピティは高 分子を材料面から捉えるだけのものであり,“纎維”を深く きめ細かく究明するものには発展しにくい，それを実現 するために, 纎維にターゲットを絞った人達の協力と研 鐟が必要であり, “繊維”専門の学会の存立意義が生じる. 繊維学会でなければできないことがあると仲間たちが認 め, 力を出し合って, 繊維学会が生まれ育った. 当然, 纎維の中でさらに絞り込んだターゲットを志向する方々

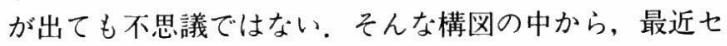
ルロース学会が発足した，逆に, 瀻維を取り巻くいくつ かの学会が統合することにより, 繊維の進歩が促される とのコンセンサスができれば、その方向に話が進むこと もあり得る．真剣に検討されるべき課題である.

\section{材料と技術}

もう一点, 纎維学会のアイデンティティを示したい. 図 1 は“材料”という車輪と“技術”という車輪からな る“工学”という車を示す。材料という車輪の側に注目 していただきたい，分類のレベルが異なる様々の材料を 記入したが，それぞれについて学会ができ得る．分類の レベルが大きすぎて，あるいは小さすぎて，目的の材料 を極められないとき，それにふさわしい区切り方でまと まればよいということになる。ここで、材料という車輪 の中の “緎維”の特殊性を指摘しておかなければならな い. 前述の高分子の内訳の分類(ゴム、プラスチックス, 纎維)は, 高分子の凝集力の強さが用途上重ねられて決め

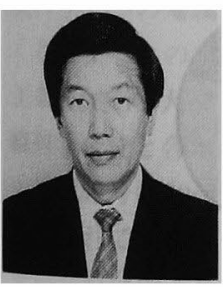

著者紹介 HARUMA KAWAGUCHI

Department of Applied Chemistry, Faculty of Science \& Technology, Keio University

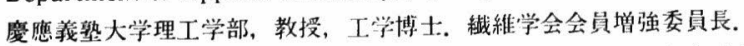

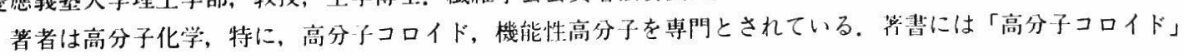
(共立出版, 1989)がある。趣味は旅。

本稿では，䢂維学会をわかりやすく紹介していただいた。 


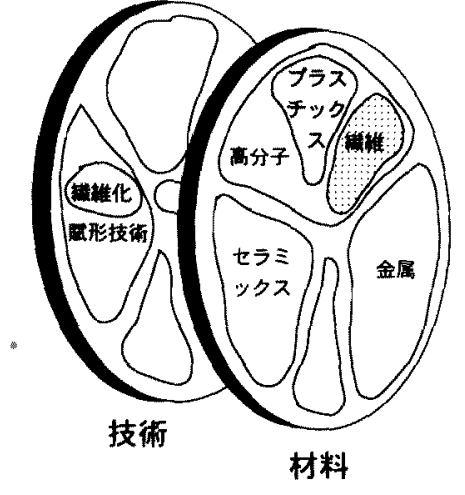

图 1 工学という車を作る再輪，材料と技術

られた分類であって，学術的とは言い難い，他の2つと 違つて繊維だけが“形”を限定されている。ゴム、プラ スチックスと並べて絨維と書いても奇異に感じられない ことは，“凝集力が大きく結晶性の高い高分子=䄉維”と の式が了承されていたことであり、“䋐維”の言葉の含み の大きさを示しているとも言える，何はともあれ，繊維 は材料のもつ形態の一つでもあり，形態を作り出す技術 と結び付けて扱われるへきものである。すなおち，繊維 は，図 1 の“技術”の車輪の中で，一次元材料の形成技 術という領域をも占めているわけで，戴維が工学上楅め て重要な役割をもっていると認識できる。

“工学”という車の上に人々の生活が乗る、“工学”と いう車がしっがすると“産業”という大物が乗ること ができる。逆に，産紧はしつかりした工学を要求子る。

工学と産業が互いに向上させあう構目を描くことができ る。繊維産業と繊維学会の協力関係の必要性を素㨁に認 めていただけると思う。闵2に示すように，瀻維学会会 員の構成を見ると企業人が約 5 割を占める。高分子学会 には及ばないが，産業界の奇与の大きな学会であるとい 之る。

図2はそういうことを示そうとして作ってみたもの であったが、别の点で読者を愕然とさせるに違いない。 ショックの種は、纎維学会の，学生会員の比率の晎常な
低さである，学生を引きつける方策を真剣に考えなけれ ばなら右いことが誰の目にも明らかであろう。若者を引 きつけるために，学会が今までしてきたこと，つい最近 始めたことは，後に述へる。 それに加える何かを考えな がら先に進も方。

\section{学会は研究成果発表の場を与える}

学会の定款を読むと，学会がすることが列記されてい て，まず，研究発表会を開催するとある，会員の研究成 果の口頭発表は繊維学会年次大会研究発表会と秋季研究 発表全で行われる，年次大会研究発表会や秋季研究発表 会でのセッションをみると繊維学会の研究予野が明確に なる、最近のそれを書き出してみる、

イ、緎維・フィルムの物理，口，高強度・高弹性率䋐 維材料，八，複合材料，二，接着と界面の科学，木，紡 織・繊維機械，人、テキス夕イルサイエンス，卜，械維

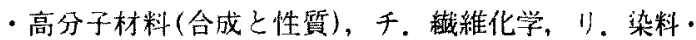
染色・仕上加工，邓，紙・バルフ，ル，消費科学， ヨ。

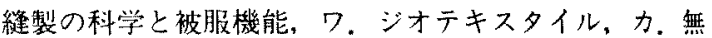
機・金属纎維， ヨ、その他

これらのセッションを眺めると, 繊維学会が, 一次元 の瀻維から二次元の布はく，フィルムまでを研究の対象 とし，製造から着衣さらには工業用途まで，また化学か ら物理までを広く視野に入れていることがわかる，年次 大会研究発表会のセッションには，適宜小さな変更がな されている。七ッション名がややや不揃いでまとまりを欠 いているのは，小さな变更の積み重故の結果である。近々， すっきりした形になるようセッションの組直しが行われ ようとしている。ここに述べなセッションは口碩発表の もので，今年の年次大会研究発表会には，若手研究者の ポスターセッションが加えられた，若手の研究を活性化 する一つの方策で，第一回目の順調な実績加ら，今後も 継続されることになるであるう。

なお，年次大会研究発表会の説明はこれだけでは終わ らない，実は䋐維学会は，十余年前から䋐維の周辺に声 をかけ，年次大会を賑やかに盛り上げ，願わくは織維の

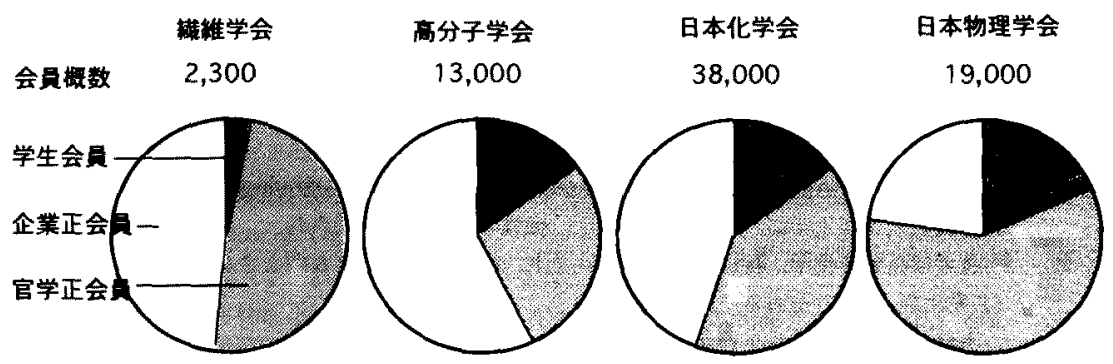

図 2 諸学会の会貝構成 
格組死を搪張しよう上の意网で，次のような特別シンポ シウムを併催するようになった,

・オプティックスとエレクトロニクス有機材料に関する シンボシウム

・生体轼維と生医学材料に関するシンポジウム ・バイオテクノロジーに関するシンポジウム

・膜一その基礎科学上技術一に関するシンボジウム ・感覚と計測に関するシンポジウム

いずれのシンポジウムももう10回以上回者重极てきた。 シンポシウム発是の当時を変和的才、今もこれらのシン ポシウムには非会員でも発表ができることになっている。 この事実の意味は深長である。傤維学会がこれらシンボ ジウムの領域を未だに本体中に取り込めないているる結果 と解释するなら，上の事寒は瀻維学会の弱点と映る。境 界領域の研究の活性化に繊維学全が一肌脱いでいるとみ れば，峨維学会の見識と読み上れる。

研究成果の、形に残る発表の形式は，学会誌への投稿

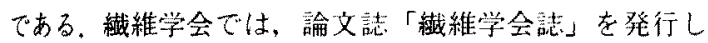
ており，年間約60件の一般報文、約20件の技術報文，約 20件のノート・研究速報が揭載されている，最近は，そ のうち3㓶以上が英文で書かれたものになっている。且 本で発行されている織維の論文誌としては唯一のものて あり、50年以上の歴史をもつ老赤論文誌であるかたわ的， Textile Research Journalとアブストラクトを载せ合うよ うにするなど世界への展開をも图っている，とはいえ， サーキュレーションの限界やサイテイション頻度の伸び 接瓜，関連他誌との競合など、考之なければならない課 题を抱えていることも事赛で, “Sen-i Gakkaishi”の誌名 も時に議諭の種となっている。

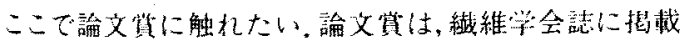
きれた論文のうち特に優れた餏文の40才末満の主著者に 贈られるもので，若い人にはこれを緎維研究の意欲と励 みに活用していただきたい，なお，研究業績の表彰には 諭文賞の他に，学会賞，技術賞がある。また，䋐維と瀻 維学会に対する貢献に对しては功緽筫加設けられている。

\section{会誌が学会と会冒を結ぶ}

学会の活動の中で“会読”は，100\%の会是とコンタク トできる唯一の手だてである。したがって，会誌は，全 員の学会への帰属意識と学会との連帯感をもっ上も大を 〈左右するものであるといえる。械維学会では、「䋐維と I業」がそ大役を担っている、「䋐維上I箖」は前述の 载維学会誌と合本の形で毎月20日頃会員に送られてくる. 本編は每号約30ページで，編集委員会の努力の結昆が盛 り这まれている。ただ、諰面が，編集する側からのメッ セージだけで占められ，会員からの声が見えてこないの
は菽しい，本特集㕫では，会貟からの意見や注文を吸い 上げるきっかけになることを期待して，様々な方々の䋐 維学会への声を集めた。自発的にそういう韾があちこち から奇せら机ると䋐維学全が活䣄つくく。

\section{学会は学習の場・情報収集の場を提供する}

繊維学会が行うことの第3点として、夏期セミナーや

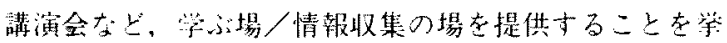
げ上う。夏季セミナーは 8 月に2 泊3 日で参加者が寝食 を共にして学湯である。また，人と人との交流の場で もあり、このセミナーには熱烈なファンが索い、日上り がそしくなってきた昨今，また，情報があふれていいる状 沉と相まって，往時ほど夏季セミナーに盛り上がりがな いとの声も范るが，一度出かけていただけばその意義上 良さを理解できると想う。

学倪の場上して，研究委員全は重要である。繊維学全 には，織維基礘科学研究委員会，染色研究委員会，織維 加工研究委員会、感党と計測研究委員会, 被服科学研究 委員会，紙・パルブ研究委員会、オプティックスとエレ クトロニクス研究委員会, 先端䄳維素材研究委員会, ウ エザリング研究委能会、ジオテキスタイル研究委是会, 感性研究フォーラム，と11の研究委員会がある。こうい 方組織はどこの学会に舟存在子る。高分子学全内には26 の研究全がある上は先に述心たし，日本化等会にも例 えば，コロイド拈り゙界面化学部会、バイオテクノロジ 一部会奆どがある。ただし、纎維学会の中の研究委員会 と、日本化学全や高分子学会の中の研究会上の間には大 きな遠いがある、後者の研究会のメンパーは100\%本体学 会の会員であるのに対して、紴維学全の研究委員会のメ ンバーは必ずしも繊䧴学会員ではない点である。具体的 にいえばないていの研究委員全では8割かそれ以上が 䋐維学全員であるが、中には学会員が50\%に満なない研 究委員会もある。学会がコントロールしき机ない研究委 員会をしっていることの是非は意見の分かれるところで

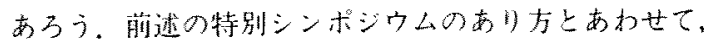

議諭する必要がある上私は思っている。

䋐維学会では年間本部・支部合わせて約20件の講演会 や講座を開㒛している。情報の氾濫上いう点では, 講演 会類の企画/連嘗が難しい時代になった。ういう中で， 恒例の新䋐維の紹介のための講演会か確実に人を集めて いるのは心強い，，関保者の意気込みの割に今心 盛り上がりに则終かる講演会も方る。欲しい情報を 欲しい人にサービスするとい目的に，今の時代，講演 全がベストな手段か，閏われるところであるか，特流に 即した满演全を企画し, face to faceの情報伝達の㙨全を 存続させることは意䔐がある。 
ここで，本年度からスタートした緎維基礎講坐を紹介 する。瀻維の研究開発のた如の基㗪知識と緎維研究の面 白さを体得していただくことを目指すこの講座は，まず は好評のうちに初年度分老終えた。講坐の受講者には修 了証書が授与されるが、この修了証書が重みを持つもの になるよう，学全では，次年度以降も講座孛継続し，実 維を棈两重格てい人。

\section{Local and Global}

地域と世界，对峙するこの双方向にバランスよく対心 することが時代の要請になってきている，繊維学会でい 之ば，地域心ついては支部活動，世界については諸外国

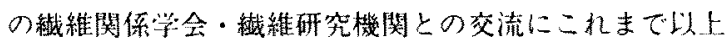
に力をいれている。

緎維学会は，東北·北海道支部，関東支部，東海支部、

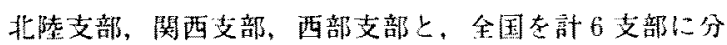
割して各地域の活動を促している。6支部の内，中部地 カに2支部あることが纎維学全の一つの特徵といってよ いであるう。

地方では，学会がらの直接のサービスは，全誌を除け ば目下のところ、支部产催の㩐演会に限られてしまうか もしれない，全员密度が高い支部では，修士論文発表会 を催して学生会員の活珄化を园つているとこるもある。 闹じ会費で地区により受けられるサービスに差買がある のは氛になるところである。夏季セミナ一を地方支部に 委部して地区活動活性化の一助としているが，時には， 地方支部に会婄の特集号の編集を任せてみるのはどうで あろう。支部の方々に学全との一体感を持っていただく のに效果があると思之る。

全国会是，あるいは全世哭の関係者への情都サ一ビス はやがてはインターネットが担うことになる。しかし， インターネットによる学会の情報サービス業務はまだこ れからの課題である.今のところ，学全は次の大学の 2 研觉空のお世話による間借りのホームペーシしが持って W. th,

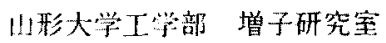

http : //cmasuko2,yz yamagata-u.ac.jp/SFST/ index 1.html

索都工芸赫維大学 梶原研究宝

http : //www.chem.kit.ac.jp/kansai

このアトレスにアタセスして，閧りのホームページに
つけての感想を聞がせていただきない。るして，我こを はという苦い方々に，自前のホームへーシの本格的な故 ちたげお願いしようと思う。

国際化への学全の步みにも触れておきたい。㵶維学全

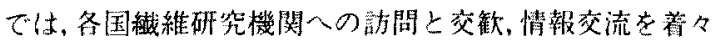
と進めている。特にアジア近郊諸国との繊維研究体制の 確机に努めている。1999年には第5回アジアテキタイ ルコンファレンス(ATC)が日本で行われることになって いる.

\section{学会は人材を育成する}

緎維学会の事業の中で特筆したいの材人育成である。

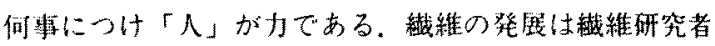

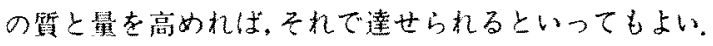
織維学会は創立以来当然人材育成に努めてきたが，剧立

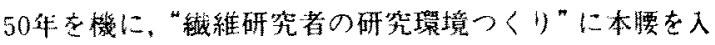
机，次のような县体策を実行し始め心，

、研究助成

- 若手研究者の悩張補助

・研究センタ一設主計画

前 2 者は大学地宦公の研究所の研究者索封象とするも のである。研究助成は研究費給付, 出張補助は海外での 研登発表のための出張費補助である。発足しなばかりで まだ周知されていないか，会䝿、特に萑手研究者にはこ の制度を利用していただきたい。

研焭センタ一構想の力は，施設の設置を伴う、壮大て 萝のある話である。瀻維研究者の育成，社会人再教育を 目的としていることから，廉等双方から熱い期待が寄世

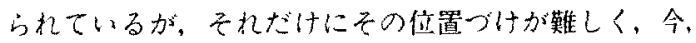
慎重に搆想が練られている。

\section{あとがき}

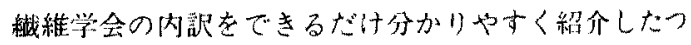

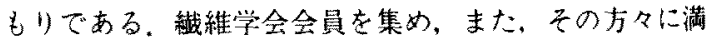
足感を持っていただくためは，“全買だから得的玌るも の゙が量・質其マ豊かでなけ估ばらない、ここで述へ ホことがその要求をとの程度满たす舟の加分からない。 足りないものはこ机か的足していかなけ札ばならない。 そのことを祍者のみなさんにやっていたな゙きない，受け 身の一会員でなく，働きかける会員になって、“絩維”と “織維学全”を育てて欲しい。 